\title{
INOVASI KURIKULUM DALAM DIMENSI TAHAPAN PENGEMBANGAN KURIKULUM PENDIDIKAN AGAMA ISLAM
}

\author{
Sigit Tri Utomo \\ STAINU Temanggung, Jawa Tengah, Indonesia \\ Sigittriutomosukses@gmail.com \\ Luluk Ifadah \\ STAINU Temanggung, Jawa Tengah, Indonesi $a$ \\ Bundaqotrunnada@gmail.com
}

\begin{abstract}
This paper contains an explanation of understanding about curriculum innovation in the dimensions of the stages of curriculum development in Islamic religious education. The curriculum becomes very important in educational institutions because the curriculum is the "heart" of education. The data collection method in this research uses literature study. In this writing, the analysis used with hermeneutics, the writer explains that behind the text there is context meaning or behind the explicit meaning there is an explicit meaning if interpreted literally can be interpreted as an interpretation or interpretation. The writer also uses synthesis analysis and content analysis. The results showed that the curriculum is a set of tools to achieve a goal, starting from planning as the first stage, in the form of planning, such as; strategic planning program planning, such as; module-based program based programs, competency-based programs or school-based entrepreneurship and planning of learning activities, while the second stage of implementation up to evaluation. In the dimension of the stages of curriculum development of Islamic religious education at least pay attention to a number of things such as the foundation of theology, foundation of philosophy, social foundation, foundation of psychology and foundation of Pancasila and foundation of technology. Whereas the principles in developing PAI curriculum are the principles of relevance, effectiveness, efficiency, sustainability, flexibility and integrity. Based on the concept of curriculum development in Islamic education and the stages of its development, a curriculum developer after paying attention to the characteristics of the Islamic education curriculum, the basics that become his foundation in developing curriculum, the principles of curriculum development, then he must determine which approach will be carried out. in curriculum development; such as the field of study approach, interdisciplinary approach, reconstruction approach, humanistic approach, or national development approach.
\end{abstract}

Keywords: Curriculum Innovation, Dimensions of Stages, PAI Curriculum Development

Abstrak: Tulisan ini berisi pemaparan pemahaman tentang inovasi kurikulum dalam dimensi tahapan pengembangan kurikulum pendidikan agama islam. Kurikulum menjadi sangat penting dalam lembaga pendidikan karena kurikulum adalah "jantung" nya pendidikan. Metode pengumpulan data dalam penelitian ini menggunakan studi pustaka. Dalam penulisan ini, analisis yang digunakan dengan hermeneutika, yakni penulis memaparkan dibalik teks ada makna konteks atau dibalik makna tersurat ada arti tersurat jika diartikan secara harfiah dapat diartikan sebagai penafsiran atau interpretasi. Penulis juga menggunakan analisis sintesis dan content analysis. Hasil penelitian menunjukkan bahwa kurikulum merupakan seperangkat alat untuk mencapai sebuah tujuan, mulai dari perencanaan seperti tahapan pertama, berupa perencanaan, seperti; perencanaan strategis perencanaan program, seperti; program berbasis program berbasis modul, program berbasis 
JRTIE: Journal of Research and Thought of Islamic Education

Vol. 3, No. 1, April 2020

kompetensi ataupun kewirausahaan berbasis sekolah dan perencanaan kegiatan pembelajaran,sedangkan tahapan kedua implementasi sampai dengan evaluasi. Dalam dimensi tahapan pengembangan kurikulum pendidikan agama islam setidaknya memperhatikan beberapa hal seperti landasan teologi, landasan filosofi, landasan sosial, landasan psikologi dan landasan pancasila serta landasan teknologi. Sedangkan dalam prinsip dalam pengembangan kurikulum PAI yaitu prinsip relevansi, efektivitas, efisensi, berkesinambungan, fleksibilitas dan integritas. Berdasarkan konsep pengembangan kurikulum pendidikan Islam dan tahapan-tahapan pengembangannya, maka seorang pengembang kurikulum setelah memerhatikan ciri-ciri kurikulum pendidikan Islamdasardasar yang menjadi pijakan dirinya dalam melakukan pengembangan kurikulum, prinsipprinsip pengembangan kurikulum, maka ia harus menentukan pendekatan manakah yang akan dilakukan dalam pengembangan kurikulum; seperti pendekatan bidang studi, pendekatan interdisipliner, pendekatan rekonstruksionisme, pendekatan humanistik, atau pendekatan pembangunan nasional.

Keywords: Inovasi Kurikulum, Dimensi Tahapan, Pengembangan Kurikulum PAI

\section{A. PENDAHULUAN}

Kurikulum merupakan salah satu perangkat yang harus ada dalam suatu lembaga pendidikan. Kurikulum memegang peranan yang cukup strategis dalam mencapai tujuan pendidikan, baik itu pendidikan umum maupun pendidikan agama. ${ }^{1}$ Tujuan pendidikan agama Islam adalah untuk terwujudnya insan kamil yang memiliki integritas iman, moral, dan amal, adanya kesatuan antara jasmani dan rohani, dunia dan akhirat. Dengan kata lain, pendidikan Agama Islam harus menyentuh tiga ranah, yaitu hati (heart) atau afektif, akal (head) atau kognitif, jasmaniyah (hand) atau psikomotorik. Ketiganya harus berjalan secara simultan, integratif dan holistik. Dengan demikian, kurikulum yang dipandang baik untuk mencapai tujuan PAI adalah yang bersifat integrated dan komprehensif, mencakup ilmu yang dibutuhkan dalam kehidupan duniawi dan ilmu yang dibutuhkan dalam kehidupan ukhrawi kelak. ${ }^{2}$

Pendidikan merupakan salah satu jalan untuk membentuk manusia menjadi pribadi cerdas, bermoral, dan bertanggungjawab. Melalui pendidikan seseorang dapat mengembangkan sikap, pengetahuan, maupun keterampilan secara optimal. Dalam Undang-Undang No. 20 Tahun 2003 tentang Sistem Pendidikan Nasional disebutkan bahwa pendidikan adalah usaha sadar dan terencana untuk

${ }^{1}$ Marliana, "Anatomi Kurikulum Pendidikan Agama Islam Di Sekolah" Dinamika Ilmu, Vol. 13 No. 2, Desember 2013, hlm. 137.

2 Abudin Nata, Filsafat Pendidikan Islam 1 (Jakarta: Logos Wacana Ilmu, 1997), hlm. 127. 
JRTIE: Journal of Research and Thought of Islamic Education

Vol. 3, No. 1, April 2020

mewujudkan suasana belajar dan proses pembelajaran agar peserta didik secara aktif mengembangkan potensi dirinya untuk memiliki kekuatan spiritual keagamaan, pengendalian diri, kepribadian, kecerdasan, akhlak mulia, serta keterampilan yang diperlukan dirinya, masyarakat, bangsa dan negara. Dalam konteks ini, pendidikan nasional Indonesia berfungsi mengembangkan kemampuan dan membentuk watak serta peradaban bangsa yang bermartabat dalam rangka mencerdaskan kehidupan bangsa. Di samping itu, bertujuan untuk berkembangnya potensi peserta didik agar menjadi manusia yang beriman dan bertaqwa kepada Tuhan Yang Maha Esa, berakhlak mulia, sehat, berilmu, cakap, kreatif, mandiri, dan menjadi warga negara yang demokratis serta bertanggungjawab. ${ }^{3}$

Sedangkan tujuan kurikulum dirumuskan berdasarkan perkembangan tuntutan, kebutuhan dan kondisi masyarakat serta didasari oleh pemikiranpemikiran dan terarah pada pencapaian nilai-nilai filosofis, terutama falsafah negara. Kurikulum sebagai salah satu komponen pendidikan sangat berperan dalam mengantarkan pada tujuan pendidikan yang diharapkan. Untuk itu kurikulum merupakan kekuatan utama yang mempengaruhi dan membentuk proses pembelajaran. Kesalahan dalam penyusunan kurikulum akan menyebabkan kegagalan suatu pendidikan dan penzaliman terhadap peserta didik. ${ }^{4}$ Pengalaman suatu waktu terdiri dari aspek yang saling berhubungan dan rentetan kejadian. ${ }^{5}$

Dalam keseluruhan proses pendidikan di sekolah, kegiatan belajar merupakan kegiatan yang paling pokok. Ini berarti bahwa berhasil tidaknya pencapaian tujuan pendidikan banyak bergantung kepada bagaimana proses belajar yang dialami oleh peserta didik. Belajar dan mengajar merupakan dua konsep yang tidak bisa dipisahkan satu sama lain, dua konsep tersebut menjadi terpadu dalam suatu kegiatan manakala terjadi interaksi pendidik dengan peserta didik, peserta didik dengan peserta didik, pada saat pengajaran itu berlangsung. Inilah makna belajar dan mengajar sebagai suatu proses interaksi pendidik dengan peserta didik sebagai

${ }^{3}$ M. Fadlillah, "Aliran Progersivisme dlam Pendidikan Islam di Indonesia", Jurnal Dimensi Pendidikan dan Pembelajaran Vol. 5 No. 1 Januari 2017, hlm 1-8

4 Ramayulis dan Samsul Nizar, Filsafat Pendidikan Islam (Jakarta: Kalam Mulia, 2010), hlm. 194.

5 Soedjono, Aliran Baru dalam Pendidikan, (Bandung: CV Ilmu 2008), hlm. 128-130 
JRTIE: Journal of Research and Thought of Islamic Education

Vol. 3, No. 1, April 2020

makna utama proses pembelajaran yang memegang peranan penting untuk mencapai tujuan pengajaran yang efektif. ${ }^{6}$

Usaha untuk menciptakan kondisi pembelajaran yang dapat melibatkan peran aktif peserta didik, membutuhkan kemampuan pendidik dalam menerapkan model pembelajaran yang sesuai dan bervariasi agar peserta didik tidak merasa bosan. Adanya keterlibatan peserta didik dalam proses pembelajaran akan menumbuhkan motivasi yang tinggi dan pada akhirnya berpengaruh terhadap peningkatan hasil belajar. $^{7}$ Sebagai pendidik yang memiliki tugas pengembangan potensi peserta didik, jelaslah seorang guru harus mengimprovisasikan kemampuannya dengan berbagai upaya, diantaranya dengan menulis, berdiskusi, mengikuti kegiatan ilmiah, mengikuti kegiatan seminar, dan kegiatan yang lain yang mampu mengasah tugas mulianya sebagai pendidik. Karena beberapa kompetensi yang harus dikembangkan adalah kompetensi sosial, kompetensi, paedagogik, dan kompetensi profesional. Seorang guru yang baik adalah mereka yang memenuhi persyaratan kemampuan profesional baik sebagai pendidik. Letak pentingnya standar mutu profesional guru untuk menjamin proses belajar mengajar dan hasil yang bermutu. ${ }^{8}$ Sebenarnya tidak terlalu sulit bagi sejumlah praktisi pendidikan untuk mengembangkan kurikulum manakala bentuk kehidupan era global itu sudah nyata. Yang sukar adalah memprediksi gambaran kehidupan masa depan yang belum jelas. Karena itu, untuk dapat merancang dan mengembangkan kurikulum yang adaptable dengan kehidupan di era global, terlebih dulu harus memahami berbagai kecenderungan yang menjadi ciri pokok kehidupan di era global.

\section{B. MAKNA INOVASI MANAJEMEN KURIKULUM PAI}

Inovasi secara etimologi berasal dari kata Latin innovation yang berarti pembaharuan atau perubahan. Kata kerjanya innovo yang artinya memperbaharui dan mengubah, inovasi ialah suatu perubahan yang baru menuju ke arah perbaikan, yang lain atau berbeda dari yang ada sebelumnya, yang dilakukan dengan sengaja hlm. 28.

${ }^{6}$ Nana Sudjana, Dasar-Dasar Proses Belajar Mengajar, (Bandung : Sinar Baru Algensindo, 2002),

${ }^{7}$ Oemar Hamalik, Pendekatan Baru Strategi Belajar Mengajar Berdasarkan CBSA, (Bandung: Sinar Baru Algensindo, 2003), Cet. 3, hlm. 18.

8 Anwar Jasin, Pengembangan Standar Profesional Guru dalam Rangka Peningkatan Mutu Sumber Daya Manusia, dalam M. Dawam Rahajo, (ed.), Keluar dari Kemeut Pendidikan Nasional: Menjawab Tantangan Kualitas Sumber Daya Manusia Abad (SDM) 21, (Jakarta: PT Intermasa, 1997), hlm. 25. 
JRTIE: Journal of Research and Thought of Islamic Education

Vol. 3, No. 1, April 2020

dan berencana (tidak secara kebetulan). Istilah perubahan dan pembaharuan ada perbedaan serta persamaanya. Perbedaannya, kalau pada pembaharuan ada unsur kesengajaan. Persamaannya. Yakni sama-sama memiliki unsur yang baru atau lain dari yang sebelumnya. Kata "Baru" dapat juga diartikan apa saja yang baru dipahami, diterima, atau dilaksanakan oleh si penerima inovasi, meskipun bukan baru lagi bagi orang lain. Namun, setiap yang baru itu belum tentu baik setiap situasi, kondisi dan tempat, sedang manajemen adalah proses penggunaan sumber daya secara efektif untuk mencapai sasaran. Dalam urusan ini, pimpinan bertanggung jawab atas jalannya organisasi. ${ }^{9}$

Dalam dunia pendidikan, kurikulum merupakan istilah yang diadopsi dari tradisi olahraga lari. Kurikulum berasal dari bahasa Perancis " courier " yang berarti berlari dan "curere" yang berarti tempat berpacu. Curriculum diartikan jarak yang harus ditempuh oleh pelari. Dari makna yang terkandung berdasarkan rumusan masalah tersebut, kurikulum dalam pendidikan diartikan sebagai jumlah mata pelajaran yang harus ditempuh atau diselesaikan peserta didik untuk memperoleh ijazah. ${ }^{10}$ Kurikulum dimaksudkan sebagai pedoman yang memberikan arah dan tujuan pembelajaran agar Tujuan Pendidikan Nasional dapat tercapai. ${ }^{11}$ Kurikulum digunakan dalam dunia pendidikan baru pada abad ke-20. Dalam konteks pendidikan, kurikulum diartikan sebagai jangka waktu pendidikan yang harus ditempuh oleh peserta didik yang bertujuan untuk memperoleh ijazah.

Para pakar pendidikan seperti Hilda Taba, Saylor \& Alexander, Smith, dan Jhon Kerr memiliki definisi kurikulum yang berbeda-beda. Hilda Taba, misalnya, mendefinisikan kurikulum sebagai "a plan for learning." Definisi Taba ini sangat sempit, karena hanya menekankan pada rencana pembelajaran saja. Definisi agak luas dikemukakan oleh Saylor \& Alexander: "the total effort of the school situation."12

\footnotetext{
${ }^{9}$ Kamisa, Kamus Lengkap Bahasa Indonesia (Surabaya: Kartika, 1997), hlm. 358.

10 Nana Sudjana.Pembinaan dan Pengembangan Kurikulum Di Sekolah, (Jakarta: Sinar Baru Algensindo), hlm.3.

${ }^{11}$ Fungsi dan Tujuan Pendidikan Nasional yaitu: "Pendidikan Nasional berfungsi mengembangkan kemampuan dan membentuk watak serta peradaban bangsa yang bermartabat, bertujuan untuk berkembangnya potensi peserta didik agar menjadi manusia yang beriman dan bertaqwa kepada Tuhan Yang Maha Esa, berakhlak mulia, sehat, berilmu, kretif, mandiri, dan menjadi warga Negara yang demokratis serta bertanggungjawab". Lihat UU Sisdiknas Nomor 20 Tahun 2003 Bab II Pasal 3.

12 Nasution, Pengembangan Kurikulum (Bandung: Alumni, 1988), hlm. 10.
} 
JRTIE: Journal of Research and Thought of Islamic Education

Vol. 3, No. 1, April 2020

Definisi ini dikatakan agak luas, karena mencakup semua usaha yang dilakukan sekolah untuk mencapai tujuan yang diinginkan baik pada situasi di dalam maupun di luar sekolah. Definisi yang lebih luas dikemukakan oleh Smith: " $a$ squence of potential expriences of disciplining children and youth in group ways of thinking and acting." 13 Lebih jauh, James A. Beane dalam karyanya Curriculum Planning and Development, menyimpulkan adanya empat kategori pengertian kurikulum, yaitu: (1) kurikulum sebagai produk (curriculum as product), (2) kurikulum sebagai program (curriculum as a program), (3) kurikulum sebagai materi pembelajaran yang diperlukan (curriculum as intented learnings), dan (4) kurikulum sebagai pengalaman peserta didik (curriculum as the expriences of the learner). ${ }^{14}$

Karena sebenarnya tujuan keberhasilan dalam pendidikan yaitu mampu memberikan bekal dalam menyelesaikan masalah kehidupannya yang dihadapi dengan bijaksana. Ada keyakinan pragmatisme bahwa akal manusia sangat aktif dan ingin selalu meneliti, tidak pasif dan tidak begitu saja menerima pandangan tertentu sebelum dibuktikan kebenaranya secara empiris. ${ }^{15}$ Proses pendidikan seumur hidup (live long education). Hal ini sejalan dengan konsep pendidikan Islam. Muhaimin ${ }^{16}$ mengatakan manusia harus sejalan dengan hidupnya. Karena pendidikan sejatinya pengembangan optimal kemampuan manusia, pengembangan optimal kreasi wahana kehidupan manusia sebagai makhluk sosial dan makhluk Allah. ${ }^{17}$

\section{TAHAPAN PENGEMBANGAN KURIKULUM PAI}

\section{Perencanaan Kurikulum}

Tahap awal pengembangan kurikulum adalah perencanaan. Dalam pengembangan kurikulum, ada tiga aspek yang dapat dikembangkan, yaitu pengembangan pada aspek tujuan, pengembangan aspek materi, dan pengembangan pada tata kelola lembaga Untuk mengembangkan ketiga aspek tersebut, perlu perencanaan yang matang pada ketiganya. Perencanaan dimaksud meliputi tiga kegiatan, yaitu:

13 Nasution, Pengembangan Kurikulum, hlm. 9

14 James A. Beane, et.all. Curriculum Planning and Development (United State of America: McGraw-Hill Book Company,1991), 28-29.

15Sadullah, Uyoh. (2003). Pengantar Filsafat Pendidikan. (Bandung: Alfabeta,2003), hlm. 4

16 Konsep Pendidikan islam (Solo: Ramadhan, 2003), hlm. 38

17 M. Jindar Wahyudi, Nalar Pendidikan Qurani (Yogyakarta; Apeiron Philotes, 2006), hlm. 66 


\section{a) Perencanaan strategis (strategic planning)}

Perencanaan Strategis dipahami sebagai kegiatan yang dilakukan dalam rangka perumusan standar kompetensi, penetapan isi dan struktur program, seta penyusunan strategi pelaksanaan kurikulum secara keseluruhan. Karena sifatnya strategis, maka kegiatan ini merupakan tugas dan tanggung jawab dewan dan pihak yang otoratif di suatu lembaga pendidikan. ${ }^{18}$ Kegiatan ini lazim dikoordinasikan oleh ketua yayasan dengan anggota yang terdiri dari anggota yayasan, kepala sekolah, bidang kurikulum, dan komite sekolah. Pada aspek perencanaan strategis ini, ketua yayasan harus meminta masukan dari berbagai kelompok, baik yang ada dalam lembaga yang bersangkutan maupun dari luar.

Dalam perumusan standar kompetensi, tugas para perancang kurikulum adalah menentukan pengetahuan, sikap, dan keterampilan yang diharapkan dimiliki oleh peserta didik setelah mereka menyelesaikan keseluruhan program pendidikan di suatu lembaga pendidikan. Adapun yang menjadi sumber utama dalam perumusan standar kompetensi ini adalah aliran filsafat yang diikuti, visi dan misi lembaga, harapan-harapan masyarakat, peraturan dan kebijakan pemerintah tentang pendidikan, seta tuntutan dunia usaha dan dunia kerja.

b) Perencanaan program (program planning)

Perencanaan program dipahami sebagai kegiatan-kegiatan yang dilakukan dalam rangka menyusun konmpetensi dasar dan menentapkan materi atau pokok bahasan pada setiap matapelajaran. Adapun pihak-pihak yang terlibat dalam perencanaan program ini adalah bidang kurikulum kepala sekolah, dan beberapa guru yang dipilih terutama dipilih berdasarkan keahlian disiplin ilmu dan kinerja mereka. Sebagaimana visi, misi, dan standar kompetensi yang dinyatakan dalam bentuk rumusan tertentu, menurut Peter F. Oliva, kompetensi dasar juga harus dirumuskan dalam bentuk pernyataan (statements). ${ }^{19}$

Dalam kaitan ini, perancang kurikulum bertugas menyusun dan merumuskan kompetensi dasar. Kompetensi dasar dirumuskan untuk setiap matapelajaran yng akan dicapai selama program matapelajaran tersebut diajarkan. Atas dasar ini,

${ }^{18}$ Subandijah, Pengembangan dan Inovasi Kurikulum (Jakarta: Raja Grafindo Persada, 1996), 216.

19 Peter F. Oliva, Developing the Curriculum (New York: Harper Collins Publishers Inc., 1992), 263. 
JRTIE: Journal of Research and Thought of Islamic Education

Vol. 3, No. 1, April 2020

kompetensi dasar setiap matapelajaran berbeda dengan kompetensi dasar yang akan dicapai oleh matapelajaran yang lain. Kegiatan lain dalam perencanaan program adalah penetapan materi atau pokok bahasan pada setiap matapelajaran. Dalam kegiatan ini, para perancang kurikulum bertugas menetapkan bahan kajian dan pelajaran untuk mencapai kompetensi pada masing-masing matapelajaran. Dalam hubungan ini, ada tiga prinsip yang perlu diperhatikan:

1. Materi setiap matapelajaran berupa bahan kajian atau topik-topik pelajaran yang dapat dikaji oleh peserta didik dalam proses pembelajaran;

2. Materi setiap matapelajaran mengacu pada pencapaian kompetensi dasar masing-masing satuan pendidikan. Perbedaan dalam ruang lingkup dan urutan bahan pelajaran disebabkan oleh perbedaan kompetensi dasar matapelajaran tersebut; dan

3. Materi setiap matapelajaran diarahkan untuk mencapai tujuan pendidikan nasional 20

c) Perencanaan kegiatan pembelajaran (program velivery plans). ${ }^{21}$

Perencanaan kegiatan pembelajaran dipahami sebagai kegiatan yang dilakukan dalam rangka implementasi pembelajaran yang terdiri atas: menyusun indikator pencapaian kompetensi, menetukan materi, manentukan strategi pembelajaran, dan menetapkan alat evaluasi pembelajaran yang akan digunakan. Adapun pihak yang bertugas untuk membuat perencanaan kegiatan pembelajaran ini adalah para guru. ${ }^{22}$

Bagi peserta didik, rumusan indikator pencapaian kompetensi tersebut bermanfaat untuk:

1. Mengetahui harapan guru secara jelas,

2. Menjadi pedoman untuk fokus belajar, dan

3. Mengetahui indikator-indikator yang jelas untuk mengukur keberhasilan.

Adapun bagi guru, indikator pencapaian kompetensi tersebut bermanfaat:

20 Oemar Hamalik, Kurikulum dan Pembelajaran, 25.

${ }^{21}$ Curtis R. Frinch \& Jhon R. Cruncilton, Curriculum Development in Vocational and Technical Education (Bosto and london: Allyn and Bacon, 1993), 46-48.

${ }^{22}$ Curtis R. Finch \& Jhon R. Cruncilton, Curriculum Development, 47-48. Lihat juga: Pengembangan dan Inovasi Kurikulum, 218. 
1. Untuk memilih strategi pembelajaran yang tepat, teknik pengukurandan evaluasi yang cocok

2. Membuat feed back dan evaluasi menjadi sangat jelas dan terarah;

3. Mengomunikasikan indikator pencapaian kompetensi kepada guru lain yang mengampu matapelajaran yang sama; serta

4. Untuk mengukur sejauh mana belajar dengan level yang lebih tinggi dimasukkan dalam suatu desain matapelajaran.

Kegiatan tersebut melibatkan sumber daya manusia yang memilki status yang berbeda-beda. Perbedaan status sumber daya manusia tersebut menentukan perbedaan fungsi dan perannya masing-masing dalam perencanaan kurikulum.

Untuk merumuskan indikator pencapaian kompetensi tersebut ada baiknya para guru memerhatikan rekomendasi Robert F. Mager, yang dikutip oleh S. Nasution bahwa indikator:

1. Harus spesifik dan dinyatakan dalam bentuk kelakuan yang dapa diamati dan dapat diukur, hingga manakah indikator itu tercapai;

2. Harus dinyatakan dalam kondisi apa indikator itu tercapai;

3. Harus pula ditentukan kriteria tentang tingkat keberhasilan yang harus dicapai oleh peserta didik; dan

4. Harus digunakan kata kerja yang merunjukkan apa yang dapat dilakukan peserta didik setelah belajar. ${ }^{23}$

\section{Implementasi Kurikulum}

Tahap lanjutan dalam pengembangan kurikulum setelah tahap perencanaan adalah tahap implementasi kurikulum meliputi kegiatan menerapkan semua rancangan yang tercantum dalam kurikulum tertulis. Pada tahap ini, kompetensi, program pendidikan, dan program pembelajaran yang telah direncanakan dalam situasi pembelajaran.

Menurut Curtis R. Finch \& Jhon R. Cruncilton, ada empat model implementasi kurikulum yang dapat dipilih, antara lain adalah sebagai berikut: ${ }^{24}$

a) Program pendidikan berbasis individu (individual educational program) 237.

23 S. Nasution, Pengembangan Kurikulum, 45. Lihat juga: Pengembangan dan Inovasi Kurikulum,

${ }^{24}$ Curtis R. Finch \& Jhon R. Cruncilton, Curriculum Development, 246-247. 
Model ini dipahami sebagai program pendidikan yang menempatkan peserta didik sebagai komponen utama, sementara hal lain di luar peserta didik hanya merupakan komponen yang bersifat komplementer. Apabila model ini yang dipilih untuk implementasi kurikulum, maka guru harus menempatkan komponen buku ajar, media, strategi, dan lingkungan pembelajaran yang telah direncanakan sebagai komponen yang dapat memaksimalkan serta didik dalam proses pembelajaran. Untuk itu, guru harus menguji secara seksama relevansi buku ajar, media, strtegi, dan ligkungan pembelajaran dengan kebutuhan masing-masing peserta didik.

b) Pembelajaran berbasis modul (modularized instruction)

Yang dimaksud dengan pembelajaran berbasis modul adalah kegiatan pembelajaran yang menempatkan modul sebagai komponen utama. Model pembelajaran ini didasarkan pada asumsi bahwa peserta didik akan lebih berprestasi jika dipandu oleh tujuan pembelajaran dan materi yang tersusun dalam suatu modul. Apabila model pembelajaran ini yang dipilih untuk implementasi kurikulum, maka guru harus menyesuaikan kurikulum yang telah direncanakan dengan karakteristik dan format model pembelajaran berbasis modul.

Menurut Curtis R. Finch \& Jhon R. Cruncilton, format pembelajaran berbasis modul memuat enam komponen, yaitu: pendahuluan (introduction), $\backslash$ tujuan (objectives), penilaian awal (preassessment), pengalaman belajar (learning experiences), buku ajar (resource materials), dan penilaian akhir (postassessment). ${ }^{25}$ Dengan memerhatikan format di atas, pembelajaran berbasis modul ini kompatibel dengan model program penididikan berbasis individu.

c) Pendidikan berbasis kompetensi (competency-based education)

Model ini dipahami sebagai program pendidikan yang lebih menekankan pada kompetensi (kemampuan) peserta didik, baik yang berupa pengetahuan (knowledge), tugas (tasks), keterampilan (skills), sikap (attitudes), nilai (values) mau pun penghargaan (aprecation) untuk mencapai keberhasilan 
dalam hidupnya. Apabila model ini dipilih untuk implementasi kurikulum, maka guru harus memastikan buku ajarnya memuat materi-materi yang berbasis pada kompetensi, yaitu materi-materi yang dapat mengembangkan kompetensi peserta didik. Dalam proses pembelajarannya, guru harus menggunakan beragam strategi pembelajaran seperti bermain peran (role play), simulasi (simulation), dan kolaboratif agar dapat memberikan beragam pengelaman belajar bagi peserta didik, sehingga mereka memiliki kesempatan yang banyak untuk mencapai kompetensi yang diinginkan.

Untuk memastikan mereka telah mencapai kompetensi yang diinginkan, guru harus membuat kriteria tertentu dan kriteria ini ditunjukkan kepada peserta didik. Adapun alat evaluasi yang lazim digunakan untuk menilai kompetensi peserta didik adalah kinerja (performance), praktik, proyek (project), produk, dan portofolio (portfolio). ${ }^{26}$

d) Kewirausahaan berbasis sekolah (school-based enterprize).

Model ini dipahami sebagai program penididikan yang membawa kegiatan kewirausahaan ke dalam sekolah, seperti restoran, pertokoan, perusahaan, perbengkelan, dan lain-lain. Model ini melibatkan peserta didik dalam pengelolaan kegiatan kewirausahaan tersebut, sejak dari persiapan, pelaksanaan sampai pada pengembangannya.

Apabila model ini yang dipilih untuk implementasi kurikulum, maka guru harus mengajak peserta didik untuk merencanakan dan mewujudkan kegiatan-kegiatan kewirausahaan di sekolah. Dalam proses pembelajarannya, guru menggunakan pendekatan teoretik dan praktik sekaligus. Pada aspek teoretik, guru menggunakan buku ajar yang membahas jenis-jenis kewirausahaan dengan strategi ceramah dan diskusi kelompok. Pada aspek praktik, guru bekerja sama dengan organisasi, lembaga, dan para pelaku bisnis profesional di sekitar sekolahnya untuk membimbing secara langsung peserta didiknya. Dari merekalah peserta

26 Penilaian portofolio adalah penilaian kompetensi berdasarkan dokumen-dokumen yang dimilki oleh peserta didik. Kriteria penilaiannya meliputi: kelengkapan, kejelasan, kualiras informasi, keberadaan dukungan dan data grafis. Lebih jauh tentang ini, lihat Dasim Budimansyah, Model Pembelajaran Portofolio (Bandung: PT Genesindo, 2003), 103-105. 
JRTIE: Journal of Research and Thought of Islamic Education

Vol. 3, No. 1, April 2020

didik dapat belajar banyak tentang perencanaan, pelaksnaam, dan pengembangan kegiatan kewirausahaan dengan strategi belajar sambil bekerja (learning by doing). Dalam evaluasinya, guru dapat menggunakan beberapa alat evaluasi konvensional seperti tes tertulis atau tes lisan. Sementara itu, untuk aspek praktisnya, guru dapat menggunakan alat evaluasi kinerja (performance).

\section{Evaluasi Kurikulum}

Tahap terakhir dalam siklus pengembangan kurikulum adalah tahap evaluasi kurikulum. Sebagai tahap terakhir, evaluasi kurikulum merupakan kegiatan menilai perencanaan, pelaksanaan, dan hasil- hasil penggunaan suatu kurikulum. Dalam kaitan ini, Peter F. Oliva menyebut dua model evaluasi kurikulum, yaitu: (1) Model Saylor, Alexander, dan Lewis; ${ }^{27}$ (2) Model CIPP dari Stuffiebeam. Namun dalam artikel ini hanya akan diulas model yang kedua, dengan alasan yang kedua ini yang banyak dipakai oleh para pengembang kurikulum dan karena alsan lebih komprehensif, mudah, dan praktis daripada yang pertama. Model evaluasi kurikulum CIPP yang diperkenalkan oleh Daniel L. Stuffiebeam, mendefinisikan evaluasi kurikulum sebagai "proses menjelaskan secara rinci, memperoleh, dan menyediakan informasi penting untuk membuat suatu keputusan." Ada empat obyek evaluasi menurut model CIPP, yaitu: (a) konteks (context), (b) input (input), (c) proses (process), dan $(\mathrm{d})$ produk (product). Karena empat obyek inilah, model ini disebut model CIPP (Context, Input, Process, and Product).

Sedangkan kegiatan-kegiatan yang harus ditempuh dalam evaluasi model kedua ini adalah (1) proses (process), kegiatan yang memuat beberapa langkah; (2) penjelasan rinci (delineating) tentang hal-hal yang akan dievaluasi; (3) memperoleh (obtaining) data untuk keperluan evluasi; (4) menyediakan (providing) keterangan tentang ujuan evaluasi; (5) bermanfaat (useful), karena ada kriteria tertentu untuk kegiatan evaluasi; (6) informasi (imformation), deskripsi tentang data yang diperlukan; (7) keputusan (judging) tentang kriteria, nilai kerangka kerja, dan

${ }^{27}$ Model yang pertama menekankan evaluasi kurikulum kepada lima aspek, yaitu: (a) tujuan kurikulum (tujuan intitusional, kurikuler, dan tujuan pembelajaran); (b) program pendidikan secara keseluruhan, (c) segmen tertentu program pendidikan, (d) pembelajaran, dan (e) evaluasi program. 
informasi lain yang terkait dengan evaluasi; serta (8) alternatif keputusan (decision alternatives), sejumlah respons pilihan terhadap keputusan tertentu.

Evaluasi Model CIPP (Context, Input, Process, Product) disajikan seperti bagan di bawah ini:

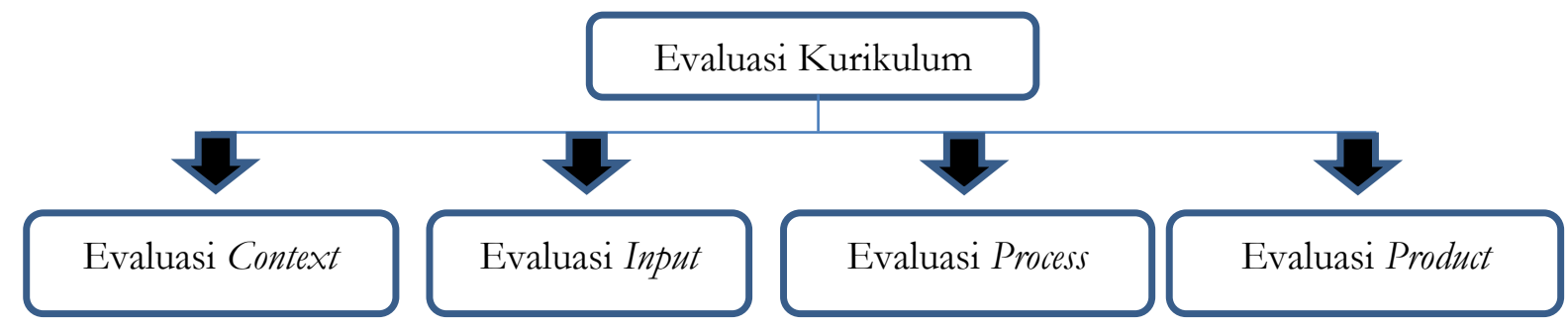

Gambar di atas menunjukkan empat aspek obyek evaluasi kurikulum. Dua aspek pertama terkait dengan evaluasi terhadap perencanaan kurikulum, sementara dua aspek yang terakhir terkait dengan evaluasi terhadap implementasi kurikulum. Keempat aspek tersebut akan dijelaskan secara singkat pada bagian berikut:

a. Evaluasi Konteks

Yang dimaksud dengan evaluasi konteks adalah evaluasi kurikulum dengan penekanan pada tujuan kurikulum. ${ }^{28}$ Atas dasar ini, data yang diperlukan untuk bahan evaluasi konteks adalah dokumen tentang rumusan tujuan kurikulum baik tujuan intitusional, tujuan kurikuler, maupun tujuan pembelajaran umum dan khusus, antara lain, alasan penentuan tujuan kurikulum, pengaitan tujuan kurikulum dengan karakteristik peserta didik, materi pembelajaran, dan tuntutan masyarakat. Selain itu,kriteri untuk melakukan evaluasi evaluasi konteks juga berupa kejelasan, ketidak ambiguan, dan kemudahan rumusan tujuan krikulum untuk dipahami. ${ }^{29}$

b. Evaluasi Input

Evaluasi input dipahami sebagai kegiatan penilaian kurikulum dengan penekanan pada sumber daya dan strategi yang digunakan untuk mencapai tujuan kurikulum. ${ }^{30}$ Atas dasar ini, data yang diperlukan untuk evaluasi input adalah keberadaan sumber daya (media, materi, dan modul) dan penggunaan strategi (strategi pembelajaran pengalaman belajar, dan lingkungan belajar). Adapun kriteria

${ }_{28}$ Peter F. Oliva, Developing the Currulum, 490. Lihat juga, Curtin R, frinch \& Jhon R. Crunkilton, Curriculum Development, 269-270

${ }^{29}$ James A. Beane, et.all., Currikulum Planning, 265-266.

30 Curtin R, frinch \& Jhon R. Crunkilton, Curriculum Development, 270. 
penilaian untuk evaluasi sumber daya adalah relevansi media, materi, dan modul dengan tujuan kurikulum; hasil dan keberterimaan peserta didik terhadap media, materi, dan modul yang telah digunakan oleh guru dalam pembelajaran. Sementara itu, kriteria penilaian untuk strategi adalah relevansi strategi pembelajarana, pengalaman belajar peserta didik, dan lingkungan belajar yang tercipta dengan tujuan kurikulum; seta hasil pelaksanaan pembelajaran dan dampaknya terhadap prestasi peserta didik. ${ }^{31}$ Berdasarkan kriteria tersebut, maka evaluasi input dapat menghasilkan simpulan antara baik (good) dan buruk (bad) pada aspek input. Dikatakan aspek input kurikulum baik, jika sumber daya dan strategi yang digunakan untuk mencapai tujuan kurikulum relevan dengan tujuan kurikulum, dapat diterima oleh peserta didik, dan berdampak positif pada pengalaman belajar peserta didik.

\section{c. Evaluasi Proses}

Yang dimaksud dengan evaluasi proses adalah kegiatan penilaian kurikulum dengan penekanan pada proses implementasi kurikulum dari awal hingga akhir. ${ }^{32}$ Dalam pengertian ini, data yang diperlukan untuk evaluasi proses adalah penggunaan buku ajar, tempat pembelajaran. Adapun kriteria penilaian untuk evaluasi proses meliputi kinerja peserta didik di kelas, kualitas pelaksanaan pembelajaran, dukungan personil, kepuasan peserta didik terhadap proses pembelajaran, dan standar tes yang digunakan. Dengan kata lain, kriteria penilaian untuk evaluasi proses berkaitan dengan dampak kurikulum terhadap perilaku dan pengalaman belajar perserta didik di sekolah.

\section{d. Evaluasi Produk}

Evaluasi produk dipahami sebagai kegiatan evaluasi dengan penekanan pada dampak kurikulum terhadap kiprah alumni di tengah-tengah masyarakat. ${ }^{33}$ Atas dasar ini, data yang diperlukan untuk evaluasi produk adalah jumlah lulusan dan keberterimaan masyarakat terhadap lulusan. Adapun kriteria penilaian untuk evalusi produk meliputi: ijazah yang diberikan kepada lulusan, kinerja lulusan dimasyarakat, dan kepuasan lulusan terhadap posisinya di masyarakat, dan

\footnotetext{
${ }^{31}$ Curtin R, frinch \& Jhon R. Crunkilton, CurriculumDevelopment, 271.

${ }^{32}$ Curtin R, frinch \& Jhon R. Crunkilton, CurriculumDevelopment, 271.

33 Peter F. Oliva, Developing the curriculum, 490.
} 
kepuasan masyarakat terhadap kinerja lulusan. ${ }^{34}$ Dengan kata lain, kriteria penilaian untuk evaluasi produk berkaitan dengan dampak kurikulum terhadap perilku dan kinerja lulusan di masyarakat dan dunia kerja. Berdasarkan kriteria penilian tersebut, maka evaluasi produk dapat menghasilkan kesimpulan bahwa dari aspek produknya, kurikulum sebuah lembaga pendidikan kemungkinan menghasilkan lulusan yang berkualitas (high quality) dan atau kurang berkualitas (low quality).

\section{Ciri-ciri Kurikulum PAI}

Kurikulum pendidikan agama Islam berbeda dengan kurikulum pendidikan pada umumnya. Yang membedakan antara dua macam kurikulum pendidikan itu adalah, kurikulum pendidikan Islam meiliki ciri umum sebagai berikut:

a. Agama dan akhlak merupakan tujuan utama serta Alqur'an dan hadits sebagai pijakan utama dalam pelaksanaan pendidikan. Selain dua sumber ajaran Islam itu, kreasi atau ijtihad para ilmuwan muslim (ulama) juga menjadi pijakan di dalam pelaksanaan pendidikan Islam.

b. Mempertahankan pengembangan dan bimbingan terhadap semua aspek pribadi siswa dari segi intelektual, psikologi, sosial, dan spiritual. Sebab, dalam Islam, seseorang tidak hanya dituntut menguasai keilmuan tetapi juga diharapkan mampu bersikap dan mengamalkan ilmu yang dipahaminya dalam kehidupan sehari-hari.

c. Adanya keseimbangan antara kandungan kurikulum dan pengalaman serta tujuan kegiatan pembelajaran. ${ }^{35}$ Pendidikan Islam tidak hanya meminta peserta didik untuk menguasai matapelajaran, tetapi juga menuntut mereka mampu membawa pengalaman yang diperolehnya ke dalam pembelajaran. Oleh karena itu dapat dikatakan, bahwa sebagai inti dari ciri-ciri kurikulum pendidikan Islam adalah kurikulum yang dapat memotivasi siswa untuk berakhlak atau berbudi pekerti luhur, baik terhadap Allah atau terhadap diri dan lingkungan sekitarnya berdasarkan ketetapan Alqur'an, hadits, serta Ijtihad ulama.

${ }^{34}$ Curtin R. Frinch \& Jhon R. Crunkilton, Curriculum Developmen, hlm. 272.

35 Armai Arief, Pengantar Ilmu Pendidikan dan Metodoologi Pendidikan Islam (Jakarta: Ciputat Press, 2002), hlm. 33. 


\section{Dasar-dasar Kurikulum PAI}

Dasar-dasar Kurikulum Pendidikan Islam Seorang pengembang kurikulum juga harus memerhatikan dasar-dasar yang menjadi pijakan lembaga di dalam menyusun atau melakukan pengembangan kurikulum. Dasar-dasar kurikulum pendidikan Islam yang perlu diperhatikan adalah:

a. Dasar Agama. Kurikulum diharapkan dapat menolong siswa dalam membina keimanan yang lebih kuat, teguh terhadap ajaran agama, berakhlak mulia dan melengkapinya dengan ilmu yang bermanfaat di dunia dan akhirat.

b. Dasar Falsafah. Pendidikan Islam harus berdasarkan wahyu Allah dan tuntunan Nabi Muhammad serta warisan para ulama.

c. Dasar Psikologis. Kurikulum tersebut harus sejalan dengan ciri perkembangan siswa, tahap kematangan, dan semua segi perkembangnnya.

d. Dasar Sosial. Kurikulum diharapkan turut serta dalam proses kemasyarakatan terhadap siswa, penyesuaian mereka dengan lingkungannya, pengetahuan dan kemahiran mereka dalam membina umat dan bangsanya. ${ }^{36}$

Kurikulum yang disusun atau dikembangkan disejalankan dengan perkembangan kebutuhan lingkungan sekitarnya, Sehingga penulis menambahkan dua dasar pengembangan kurikulum, yaitu:

e. Dasar Pancasila. Pancasila yang menjadi sebagai landasan pengembangan kurikulum PAI yang mampu menyatukan keanekaragaman

f. Dasar Teknologi. Teknologi sebagai media dalam pengembangan tahapan kurikulum PAI yang sangat berperan penting.

\section{Prinsip-Prinsip Dasar Pengembangan Kurikulum PAI}

Tentang prinsip-prinsip umum yang menjadi dasar penyusunan kurikulum pendidikan Islam, diantaranya:

a. Prinsip relevansi adalah kesesuaian pendidikan dengan lingkungan hidup siswa, relevansi dengan kehidupan masa sekarang dan akan datang, dan relevansi dengan tuntutan pekerjaan.

b. Prinsip ektifitas adalah agar kurikulum dapat menunjang efektifitas guru yang mengajar dan peserta didik yang belajar. 
c. Prinsip efisiensi adalah agar kurikulum dapat mendayagunakan waktu, tenaga, dana. Dan sumber lain secara cermat, tepat, memadai dan dapat memenuhi harapan.

d. Prinsip kesinambungan adalah saling hubungan dan jalin menjalin antara berbagai tingkat dan jenis program pendidikan.

e. Prinsip fleksibilitas artinya ada emacam ruang gerak yang memberikan sedikit kebebasan di dalam bertindak yang meliputi fleksibilitas dalam memilih program pendidikan, mengembangkan program pengajaran, serta tahap-tahap pengembangan kurikulum.

f. Prinsip integritas anatara matapelajaran, pengalaman- pengalaman, dan aktivitas yang terkandung di dalam kurikulum, begitu pula dengan pertautan antara kandungan kurikulum dengan kebutuhan siswa dan masyarakat. ${ }^{37}$

\section{Pendekatan Kurikulum PAI}

Para ahli selama ini telah mendapatkan sejumlah pendekatan umum dalam pengembangan kurikulum masing-masing berdasarkan fokus utama tertentu. Beberapa pendekatan tersebut antara lain adalah sebagai berikut :

a. Pendekatan bidang studi (pendekatan disiplin ilmu). Pendekatan ini menggunakan bidang studi atau mata pelajaran sebagai dasar organisasi kurikulum, misalnya kelompok bidang studi umum : matematika, sains, sejarah, geografi, IPA, IPS, dan sebagainya; atau kelompok bidang studi agama: fiqih, Bahasa Arab, Alqur'an-hadits, da sebagainya. Yang diutamakan dalam pendekatan ini adalah penguasaan bahan dan proses dalam disiplin ilmu tertentu.

b. Pendekatan Interdisipliner. Pendekatan ini didasarkan atas pemikiran bahwa masalah-masalah dalam kehidupan tidak hanya melibatkan satu disiplin, akan tetapi memerlukan berbagai illmu secara interdisipliner. Pendekatan ini mencakup pendekatan-pendekatan khusus, termasuk: pendekatan "BoardField", pendekatan kurikulum inti (core curiculum) ${ }^{38}$

\footnotetext{
37 M. Sulton Masyhud, Manajemen Pondok Pesantren (Jakarta: Diva Pustaka, 2003), 83.

38 M. Sulton Masyhud, Manajemen Pondok Pesantren (Jakarta: Diva Pustaka, 2003), 83.
} 
c. Pendekatan Rekonstruksionisme. Pendekatan ini juga disebut Rekontruksi sosial karena memfokuskan kurikulum pada masalah-maslah penting yang dihadapi dalam masyarakat, seperti polusi, ledakan penduduk, rasialisme, interdependensi gobal, malapetaka akibat kemajuan teknologi, perang dan damai, keadilan sosial, hak asasi manusia dan lain-lain.

d. Pendekatan Humanistik. Kurikulum ini berpusat pada siswa (student-centered), dan mengutamakan perkembangan afektif siswa sebagai prasyarat dan sebagai bagian integral dari proses belajar. Para pendidik humanistik yakin, bahwa kesejahteraan mental dan emosional siswa harus dipandang sentral dalam kurikulum, agar belajar itu memberi hasil maksimal. ${ }^{39}$

e. Pendekatan Pembangunan Nasional. Pendekatan ini terdiri dari tiga unsur utama, yaitu: (1) pendidikan kewarganegaraan (civic education), (2) pendidikan sebagai alat pembangunan nasional, dan (3) pendidikan keterampilan praktis bagi kehidupan sehari-hari.

Berdasarkan konsep pengembangan kurikulum pendidikan Islam dan tahapantahapan pengembangannya, maka seorang pengembang kurikulum setelah memerhatikan ciri-ciri kurikulum pendidikan Islam, dasar-dasar yang menjadi pijakan dirinya dalam melakukan pengembangan kurikulum, prinsip-prinsip pengembangan kurikulum, maka ia harus menentukan pendekatan manakah yang akan dilakukan dalam pengembangan kurikulum; apakah pendekatan bidang studi, pendekatan interdisipliner, pendekatan rekonstruksionisme, pendekatan humanistik, atau pendekatan pembangunan nasional.

\section{KESIMPULAN}

Di dalam memanajemen kurikulum, baik manajemen penyusunan atau pengembangan kurikulum, seorang pengembang kurikulum perlu memerhatikan tahapan-tahapan manajemen kurikulum. Ada tiga tahap di dalam memanajemen kurikulum, yaitu perencanaan kurikulum, implementasi kurikulum dan evaluasi kurikulum. Pada tahap perencanaan, pengembang kurikulum perlu memerhatikan dasar-dasar pengembangan kurikulum, prinsip-prinsip pengembangan kurikulum, dan pendekatan pengembangan kurikulum, supaya penyusunan dan 
JRTIE: Journal of Research and Thought of Islamic Education

Vol. 3, No. 1, April 2020

pengembangankurikulum tidak melenceng dari cita-cita yang diidealkan. Beberapa hal ini perlu diperhatikan, baik pada saat perencanaan strategis (strategic planning), perencanaan program (program planning), atau perencanaan kegiatan pembelajaran (program velivery plans).

Pada tahap implementasi kurikulum, guru perlu diberi pemahaman agar model pengembangan yang dipilih sejalan dengan rencana yang disusun oleh pengembang kurikulum, sedangkan model-model pengembangan kurikulum yang dapat dipilih yaitu: (1) program pendidikan berbasis individu (individual educational program), (2) pembelajaran berbasis modul (modularized instruction), (3) pendidikan berbasis kompetensi (competency- based education), dan (4) kewirausahaan berbasis sekolah (school-based enterprize). Agar, pelaksanaan kurikulum tidak melenceng dari tujuan yang ditetapkan, maka evaluasi sangat penting dilakukan, yaitu evaluasi pada: (1) tujuan kurikulum (tujuan intitusional, kurikuler, dan tujuan pembelajaran);

(2) program pendidikan secara keseluruhan, (3) segmen tertentu program pendidikan, (4) pembelajaran, dan (5) evaluasi program.

\section{DAFTAR PUSTAKA}

Arief, Armai. Pengantar Ilmu Pendidikan dan Metodoologi Pendidikan Islam Jakarta: Ciputat Press, 2002.

Curtis R. Frinch \& Jhon R. Cruncilton, Curriculum Development in Vocational and Technical Education (Bosto and london: Allyn and Bacon, 1993.

Fadlillah, M. "Aliran Progersivisme dlam Pendidikan Islam di Indonesia", Jurnal Dimensi Pendidikan dan Pembelajaran, Vol. 5 No. 1 Januari 2017.

Hamalik, Oemar. Pendekatan Baru Strategi Belajar Mengajar Berdasarkan CBSA, Bandung: Sinar Baru Algensindo, 2003.

James A. Beane, et.all. Curriculum Planning and Development United State of America: McGraw-Hill Book Company,1991.

Jasin, Anwar. Pengembangan Standar Profesional Guru dalam Rangka Peningkatan Mutu Sumber Daya Manusia, dalam M. Dawam Rahajo, (ed.), Keluar dari Kemeut Pendidikan Nasional: Menjawab Tantangan Kualitas Sumber Daya Manusia Abad (SDM) 21, Jakarta: PT Intermasa, 1970.

Jindar Wahyudi, M. Nalar Pendidikan Qurani Yogyakarta; Apeiron Philotes, 2006.

Kamisa, Kamus Lengkap Bahasa Indonesia Surbaya: Kartika, 1997.

Marliana, "Anatomi Kurikulum Pendidikan Agama Islam Di Sekolah", Dinamika Ilmu, Vol. 13 No. 2, Desember 2013. 
JRTIE: Journal of Research and Thought of Islamic Education

Vol. 3, No. 1, April 2020

Nasution, Pengembangan Kurikulum, Bandung: Alumni, 1988.

Nata, Abudin. Filsafat Pendidikan Islam 1. Jakarta: Logos Wacana Ilmu, 1997.

Peter F. Oliva, Developing the Curriculum, New York: Harper Collins Publishers Inc., 1992.

Ramayulis dan Samsul Nizar, Filsafat Pendidikan Islam, Jakarta: Kalam Mulia, 2010.

Sadullah, Uyoh. Pengantar Filsafat Pendidikan, Bandung: Alfabeta,2003.

Soedjono, Aliran Baru dalam Pendidikan, Bandung: CV Ilmu 2008.

Subandijah, Pengembangan dan Inovasi Kurikulum, Jakarta: Raja Grafindo Persada, 1996.

Sudjana, Nana. Dasar-Dasar Proses Belajar Mengajar, Bandung: Sinar Baru Algensindo, 2002.

Sudjana, Nana. Pembinaan dan Pengembangan Kurikulum Di Sekolah, Jakarta: Sinar Baru Algensindo.

Sulton Masyhud, M. Manajemen Pondok Pesantren, Jakarta: Diva Pustaka, 2003.

Undang-undang Nomor 20 Tahun 2003 tentang Sistem Pendidikan Nasional 